Table 5. Partial analysis of variance for ratings of poinsettia plants receiving varying amounts of $\mathrm{N}$ and $\mathrm{S}$ by commercial producers.

\begin{tabular}{lcccc}
\hline Source & df & Mean square & F & P > F \\
\hline $250 \mathrm{~N}$ vs. $275 \mathrm{~N}$ & 1 & 0.078 & 0.03 & 0.8549 \\
$225 \mathrm{~N}$ vs. $>225 \mathrm{~N}$ & 1 & 0.175 & 0.08 & 0.7837 \\
$200 \mathrm{~N}$ vs. $>200 \mathrm{~N}$ & 1 & 0.002 & 0.00 & 0.9762 \\
$175 \mathrm{~N}$ vs. $>175 \mathrm{~N}$ & 1 & 0.011 & 0.00 & 0.9447 \\
$150 \mathrm{~N}$ vs. $>150 \mathrm{~N}$ & 1 & 2.337 & 1.02 & 0.3185 \\
$125 \mathrm{~N}$ vs. $>125 \mathrm{~N}$ & 1 & 0.723 & 0.32 & 0.5775 \\
$100 \mathrm{~N}$ vs. $>100 \mathrm{~N}$ & 1 & 26.623 & 11.61 & 0.0015 \\
$62.5 \mathrm{~S}$ vs. $75 \mathrm{~S}$ & 1 & 1.837 & 0.80 & 0.3758 \\
$50 \mathrm{~S}$ vs. $>50 \mathrm{~S}$ & 1 & 4.188 & 1.83 & 0.1837 \\
$37.5 \mathrm{~S}$ vs. $>37.5 \mathrm{~S}$ & 1 & 5.990 & 2.61 & 0.1135 \\
$25 \mathrm{~S}$ vs. $>25 \mathrm{~S}$ & 1 & 0.457 & 0.20 & 0.6576 \\
$12.5 \mathrm{~S}$ vs. $>12.5 \mathrm{~S}$ & 1 & 12.152 & 5.30 & 0.0263 \\
0 S vs. $>0 \mathrm{~S}$ & 1 & 164.024 & 71.55 & 0.0001 \\
Error (estimated by N $\times S$ ) & 42 & 2.292 & & \\
\hline
\end{tabular}

sumer acceptance. However, $S$ at 25 $\mathrm{mg} \cdot \mathrm{L}^{-1}$ is preferable for commercial application, as this correlates to the general commercial recommendations that suggest adding $S$ at 20 to $30 \mathrm{mg} \cdot \mathrm{L}^{-1}$ if it is not available through irrigation sources (Handreck, 1986; Reddy and King, 1992). With adequate $S$ available, $N$ may be reduced from commercial recommendations of $275 \mathrm{mg} \cdot \mathrm{L}^{-1}$ (Ecke and Matkin, 1976) to $125 \mathrm{mg} \cdot \mathrm{L}^{-1}$ with no reduction in plant quality. This is a reduction in $\mathrm{N}$ application of $55 \%$ from commercial recommendations and is supported by the research results obtained by Dale et al. (1991) and Paparozzi et al. (1994). Further studies should be completed to determine the applicability of this research to the new, dark-leaved, and potentially lessnutrient-requiring genotypes currently available (Hammer, 1996).

\section{Literature cited}

Adams, S.A. 1995. Sulfur deficiency and N:S interaction in poinsettias grown in a soilless me dium. MS thesis. Univ. of Nebraska, Lincoln.

Dale, M.E., E.T. Paparozzi, and W.W. Stroup. 1991. Nitrogen sulfur interaction in poinsettia. J. Plant Nutr. 14:939-52.

Ecke, Jr., P. and O.A. Matkin. 1976. The poinsettia guide. Paul Ecke Poinsettias, Encinitas, Calif.

Hammer, P.A. 1996. Poinsettia primer. GrowerTalks 59(14)42-50.

Handreck, K.A. 1986. Critical concentrations of sulfur in liquid feeds for plants in containers. Scientia Hort. 30:1-17.

Haung, L., E.T. Paparozzi, and C. Gotway. 1997. The effect of altering nitrogen and sulfur supply on the growth of cut chrysanthemums. J.

\section{Amer. Soc. Hort. Sci. 122:559-564.}

Heintz, C.M. and A.A. Kader. 1983. Procedures for the sensory evaluation of horticultural crops. HortScience 18:18-22.

McGuire, R.G. 1992. Reporting of objective color measurements. HortScience 27:1254-55.

McLaren, K. 1976. The development of the CIE $1976\left(\mathrm{~L}^{*}, \mathrm{a}^{*}, \mathrm{~b}^{*}\right)$ uniform colour space and colourdifference formula. J. Soc. Dyers and Colourists 92:338-341.

Mortvedt, J.J. 1981. Identifying and correcting sulfur deficiencies in crop plants. Crops Soils

Nell, T.A. and R.T. Leonard. 1996. Protecting poinsettias from post production losses. GrowerTalks 60(3):98-104.

Paparozzi, E.T., P.O. Darrow, D.E. McCallister, and W.W. Stroup. 1994. The effect of varying nitrogen sulfur content on flowering poinsettia. J. Plant Nutr. 17:593-606.

Pyle, K, 1991. Water contamination regulation: What lies ahead for greenhouse growers? GrowerTalks 55(5):18-21.

Reddy, S.K. and P.A. King. 1992. Sulfur-An emerging star. GrowerTalks 55(12):79 81 .

Reddy, S.K and M.A. Madore. 1995. Is there enough sulfur in your water? GrowerTalks $58(1): 92$.

Reneau, Jr., R. B. 1983. Corn response to sulfur application in coastal plain soils. Agron. J. $75: 1036-40$.

SAS Institute, 1987. SAS user's guide: Statistics. SAS Inst., Cary, N.C.

Stroup, W.W., S.A. Adams and E.T. Paparozzi. 1998. Statistical design and analysis of producer/ consumer evaluations to assess plant quality. HortScience (In press.)

Yeager, T.H. and J.E. Barrett. 1985. Phosphorus and sulfur leaching from an incubated superphosphate-amended soilless container medium. HortScience 20:671-2. Mag. 33:11-14.
Selecting the Optimum Slowrelease Fertilizer Rate for Five Cultivars of Tissue-cultured Hosta

\author{
Wendy Britton, \\ E.J. Holcomb, and \\ David J. Beattie
}

Additional Index words. Osmocote 14-6-11.5, Sicrrablen 17-2.6-10 Plus Minors

Summary. Four rates of two slowrelease fertilizers were tested for optimum growth of five hosta cultivars: Hosta sieboldiana 'Elegans', Hosta plantaginea 'Aphrodite', Hosta 'Jade Scepter', Hosta 'Hadspen Blue', and Hosta 'Francee'. Tissue-cultured hostas from $2.5-\mathrm{cm}$ plugs were planted in 6-inch $(15-\mathrm{cm})$ pots filled with a commercial soilless medium, and the slow-release fertilizer was dibbled into the medium at $0,3,6$, or $12 \mathrm{~g} /$ pot. The plants were maintained for 4 months. Root and shoot fresh and dry weights were recorded at the end of the experiment. In addition, foliar nutrient analysis was conducted on 'Aphrodite', 'Francee', and 'Jade Sceptor'. Overall, hostas grew best when the medium was amended with $3 \mathrm{~g}$ of either Osmocote $14 \mathrm{~N}-6 \mathrm{P}-$ $11.5 \mathrm{~K}$ or Sierrablen $17 \mathrm{~N}-6 \mathrm{P}-12 \mathrm{~K}$ slow-release fertilizer.

$\mathrm{H}$ osta is the most popular shade-tolerant herbaceous perennial in the U.S. market. Because they naturally reproduce slowly by division, they are often propagated by tissue culture. Growing some tissue-cultured hosta to a saleable size in the nursery can be expensive, diffi-

The Pennsylvania State University, 103 Tyson Building, University Park, PA 16802-4200.

The cost of publishing this paper was defrayed in part by the payment of page charges. Under postal regulations, this paper therefore must be hereby marked advertisement solely to indicate this fact. 
Table 1. $P$ and F values for shoot and root dry weights (data combined for the five hosta cultivars).

\begin{tabular}{lccrc}
\hline Source & $\begin{array}{c}\text { Shoot } \\
\text { F }\end{array}$ & $\begin{array}{c}\text { Shoot } \\
\boldsymbol{P}\end{array}$ & $\begin{array}{c}\text { Root } \\
\text { F }\end{array}$ & $\begin{array}{c}\text { Root } \\
\boldsymbol{P}\end{array}$ \\
\hline Fertilizer & 0.28 & 0.6003 & 2.52 & 0.0061 \\
Rate & 4.39 & 0.0153 & 10.52 & 0.0001 \\
Fertilizer $\times$ rate & 1.33 & 0.2699 & 1.25 & 0.2929 \\
Cultivar & 5.33 & 0.0007 & 25.37 & 0.0001 \\
Cultivar $\times$ control & 1.77 & 0.1428 & 1.59 & 0.1829 \\
Cultivar $\times$ fertilizer & 1.27 & 0.2866 & 1.37 & 0.2497 \\
Cultivar $\times$ rate & 0.89 & 0.5273 & 5.12 & 0.0001 \\
\hline
\end{tabular}

cult, and time-consuming. To produce a salable hosta in a 1.0 -gal (3.8L) nursery pot from a tissue culture tube could be as short as 6 months for very vigorously growing cultivars to as long as 2 years for slow-growing cultivars.

However, there is little informa tion available on the fertilization of this popular perennial. We are aware of no specific nutritional recommendations for hosta, although it would appear that nutrition would depend on the stage of plant development. For instance, Adam ( 1988) reported that fertilization of the tuberous roots of newly transplanted field-grown Hemerocallis had no immediate effect on flowering or growth. Rather, the effect was noted during the next growing season. Similarly, fertilizing fieldgrown, spring-transplanted hosta would probably have less effect on growth during the current season than it would the next. However, many hosta are tissue cultured and sold as plugs (Nau, 1996) for which a storage root system has not had time to develop. Under these conditions, these plants would probably respond much more quickly to fertilizer application.

Research has been done to assess the optimum rate of slow-release fertilizers for a number of other plants. Blandfordia grandiflora (Christmas Bells) yielded larger plants using 4.0 $\mathrm{g} / 7.5-\mathrm{cm}$ pot of Osmocote $18 \mathrm{~N}-$ $2.6 \mathrm{P}-10 \mathrm{~K}$ compared with rates of 0 , $0.5,1.0,2.0$, and $8.0 \mathrm{~g} /$ pot (Lamont et al., 1992). Conover and Poole (1985) reported that Viburnum odoratissimum grew better with Osmocote $13 \mathrm{~N}-5.7 \mathrm{P}-10.5 \mathrm{~K}$ and Customblen 17N-3P-10K than other formulations of either Osmocote or Customblen. Brassaia actinophylla grew best with treatments of Osmocote $13 \mathrm{~N}-5.7 \mathrm{P}-10.5 \mathrm{~K}$ and $18 \mathrm{~N}-$ $2.6 \mathrm{P}-10 \mathrm{~K}$ and Customblen $17 \mathrm{~N}-$
$2.6 \mathrm{P}-10 \mathrm{~K}$ at $\mathrm{N}$ rates of $1.2,1.8$, and $2.4 \mathrm{~kg} \cdot \mathrm{m}^{-3}$ respectively. From the preceeding it is clear that the optimum slow-release fertilizer and rate must be determined for each plant species. fertilizer treatment. means at $P=0.05$.
Placement of the slow-release fertilizer may be important. The fertilizer can be topdressed or dibbled. Kovacic and Holcomb (1981) determined that topdressing a slow-release fertilizer was as effective as incorporating it. Coleman et al. (1978) determined that dibbling was as effective as incorporation.

\section{Materials and methods}

Tissue cultured plants from 2.5$\mathrm{cm}$ plugs that were $\approx 4$ months out of tissue culture of Hosta sieboldiana 'Elegans', Hosta plantaginea 'Aphrodite', Hosta' 'Jade Scepter', Hosta 'Hadspen Blue', and Hosta 'Francee' were used for this experiment because this is the starting material most frequently used by industry. The cultivars were planted

Table 2. Average shoot and root dry weights for each hosta cultivar and

\begin{tabular}{|c|c|c|c|c|}
\hline Cultivar & Fertilizer & $\begin{array}{c}\text { Rate } \\
\text { (g/pot) }\end{array}$ & $\begin{array}{l}\text { Shoot } \\
\text { wt (g) }\end{array}$ & $\begin{array}{c}\text { Root } \\
\text { wt (g) } \\
\end{array}$ \\
\hline \multirow[t]{7}{*}{ Aphrodite } & Control & 0 & $1.71 c^{2}$ & $7.20 \mathrm{~b}$ \\
\hline & Osmocote & 3 & $6.03 \mathrm{a}$ & $12.17 \mathrm{a}$ \\
\hline & & 6 & $4.92 \mathrm{~b}$ & $10.55 \mathrm{a}$ \\
\hline & & 12 & $4.23 \mathrm{~b}$ & $6.07 \mathrm{~b}$ \\
\hline & Sierra & 3 & $7.63 \mathrm{a}$ & $14.78 \mathrm{a}$ \\
\hline & & 6 & $2.93 \mathrm{bc}$ & $4.13 c$ \\
\hline & & 12 & $3.66 \mathrm{bc}$ & $4.85 \mathrm{bc}$ \\
\hline \multirow[t]{7}{*}{ Elegans } & Control & 0 & $1.70 \mathrm{~b}$ & 5.40 a \\
\hline & Osmocote & 3 & $2.18 \mathrm{~b}$ & $5.37 \mathrm{a}$ \\
\hline & & 6 & $1.12 \mathrm{~b}$ & $3.16 \mathrm{a}$ \\
\hline & & 12 & $2.61 \mathrm{~b}$ & $4.14 \mathrm{a}$ \\
\hline & Sierra & 3 & $6.94 \mathrm{a}$ & $5.79 \mathrm{a}$ \\
\hline & & 6 & $2.87 \mathrm{~b}$ & $5.40 \mathrm{a}$ \\
\hline & & 12 & $2.24 \mathrm{~b}$ & $3.37 \mathrm{a}$ \\
\hline \multirow[t]{7}{*}{ Hadspen Blue } & Control & 0 & $0.60 \mathrm{a}$ & $1.83 \mathrm{a}$ \\
\hline & Osmocote & 3 & $0.38 \mathrm{a}$ & $0.81 \mathrm{a}$ \\
\hline & & 6 & $1.07 \mathrm{a}$ & $1.68 \mathrm{a}$ \\
\hline & & 12 & $1.27 \mathrm{a}$ & $1.55 \mathrm{a}$ \\
\hline & Sierra & 3 & $1.21 \mathrm{a}$ & $1.51 \mathrm{a}$ \\
\hline & & 6 & $0.97 \mathrm{a}$ & $1.22 \mathrm{a}$ \\
\hline & & 12 & $0.69 \mathrm{a}$ & $1.06 \mathrm{a}$ \\
\hline \multirow[t]{7}{*}{ Francee } & Control & 0 & $4.11 \mathrm{a}$ & 8.86 a \\
\hline & Osmocote & 3 & $4.35 \mathrm{a}$ & $8.05 \mathrm{a}$ \\
\hline & & 6 & 3.58 a & $8.72 \mathrm{a}$ \\
\hline & & 12 & $2.97 \mathrm{a}$ & $6.28 \mathrm{a}$ \\
\hline & Sierra & 3 & $4.26 \mathrm{a}$ & $6.23 \mathrm{a}$ \\
\hline & & 6 & $3.99 \mathrm{a}$ & $8.13 \mathrm{a}$ \\
\hline & & 12 & $2.14 \mathrm{a}$ & $2.20 \mathrm{~b}$ \\
\hline \multirow[t]{7}{*}{ Jade Scepter } & Control & 0 & $1.22 \mathrm{a}$ & $3.23 \mathrm{a}$ \\
\hline & Osmocote & 3 & $3.72 \mathrm{a}$ & $5.38 \mathrm{a}$ \\
\hline & & 6 & $3.36 \mathrm{a}$ & $4.35 \mathrm{a}$ \\
\hline & & 12 & $1.87 \mathrm{a}$ & $2.94 \mathrm{a}$ \\
\hline & Sierra & 3 & $3.08 \mathrm{a}$ & $4.70 \mathrm{a}$ \\
\hline & & 6 & $2.67 \mathrm{a}$ & $3.35 \mathrm{a}$ \\
\hline & & 12 & $2.24 \mathrm{a}$ & $1.81 \mathrm{a}$ \\
\hline
\end{tabular}

${ }^{7}$ Means within a cultivar followed by the same letter are not significantly different as determined by least squares 
between 3 and 4 Dec. 1994 into 2000 $\mathrm{mL}$ (6-inch) pots filled with a commercial soilless medium (Fison's \#4, Fisons Horticulture, Inc., Warwick, N.Y.). The slow-release fertilizer (either Osmocote 14-6-11.5 (Grace Sierra, Milpitas, CA) or Sierrablen 172.6-10 plus minors (Grace Sierra, Milpitas, Calif.) was dibbled into the medium of each pot at a rate of $0,3,6$, or $12 \mathrm{~g} /$ pot . To dibble the fertilizer, a hole was made in the center of the pot, the slow-release fertilizer was added, and then the hosta plug was placed in the hole so that the plant was at the same depth that it had been growing. For the control treatment there was no hole dibbled and no fertilizer was added to the pots. The plants were arranged in four randomized complete blocks with three replications per treatment. The experiment was located in the horticulture greenhouses at Pennsylvania State Univ., University Park, Pa. Greenhouse temperature set points were $68^{\circ} \mathrm{F}\left(20^{\circ} \mathrm{C}\right)$ during the day and $60^{\circ} \mathrm{F}\left(15.5^{\circ} \mathrm{C}\right)$ at night. The plants were treated once with a micronutrient fertilizer (STEM; Peters Fertilizer Products, Fogelsville, $\mathrm{Pa}$.) by overhead watering at a rate of $2.26 \mathrm{~g} / \mathrm{gal}$.

The plants were watered overhead by hand as needed. Supplementary HID lighting at $58 \mu \mathrm{mol} \cdot \mathrm{m}^{-2} \cdot \mathrm{s}^{-1}$ PAR was provided starting 20 Jan. 1995 , and the lights were on from $6 \mathrm{AM}$ to $12 \mathrm{AM}$ daily for the duration of the experiment. The plants were harvested $18 \mathrm{Apr} .1995$, and fresh and dry weights were determined on the aerial portion. The medium was washed from the roots and the root and crown fresh and dry weights were also recorded. Ma- ture leaves of 'Aphrodite', 'Francee', and 'Jade Scepter' were randomly selected from plants within the treatment, combined into a single sample for each treatment, and analyzed for nutrient content by inductively coupled plasma atomic emission spectrometer (Dahlquist and Knoll, 1978) and Kjeldahl (Isaac and Johnson, 1976) by the Agricultural Analytical Services Laboratory at Pennsylvania State Univ. Analysis of variance using the general linear models procedure was used to statistically analyze the data obtained from harvested roots and shoots (SAS, 1989).

\section{Results and discussion}

There were no significant differences in shoot dry weight due to the type of slow-release fertilizer used, but there was a significant difference in root dry weight. There was no significant interaction between the cultivar and slow-release fertilizers used (Table 1). There was a significant difference in the shoot and root dry weights due to fertilizer rate and cultivar (Table 1 ).

The fertilizer rate of $3 \mathrm{~g}$ of either fertilizer produced significantly larger shoots than using rates of 6 and $12 \mathrm{~g}$ of fertilizer for 'Aphrodite' (Table 2). For 'Elegans' only, Sierra at 3 g produced significantly larger shoots than 6 or $12 \mathrm{~g}$ of Sierra. For the other cultivars the plants fertilized with $3 \mathrm{~g}$ were generally larger than those fertilized with 6 or $12 \mathrm{~g}$, but the differences were not significant. 'Hadspen Blue' had consistently poor growth throughout the entire experiment. The only significant difference in root dry weight was for 'Aphrodite', where 3 and $6 \mathrm{~g}$ of Osmocote and $3 \mathrm{~g}$ of Sierra produced significantly larger root dry weights than the other treatments. 'The root dry weight of the other four cultivars was not affected by fertilizer (Table 2)

For each of the three cultivars analyzed for foliar nutrient content, the $3-\mathrm{g} /$ pot treatment consistently contained the smallest percentage of $\mathrm{N}, \mathrm{P}$, and $\mathrm{K}$ of all the fertilizer treatments except the control (Table 3 ). All of the control plants $(0 \mathrm{~g} / \mathrm{pot})$ contained similar percentages of $\mathrm{N}, \mathrm{P}, \mathrm{K}$, $\mathrm{Ca}$, and $\mathrm{Mg}$. 'Aphrodite' average shoot weight was the largest of all five cultivars and had the smallest percentage of $\mathrm{N}$ for all rates of slow-rclease fertilizer compared to 'Francee' and 'Jade Scepter' ('Tables 2 and 3 ).

It is of interest to note that nutrient analysis for the leaves of 'Jade Scepter' revealed higher levels of $\mathrm{Na}$ than the leaves of 'Francee' and 'Aphrodite.' High levels of $\mathrm{Na}$ usually inhibit the uptake of $\mathrm{Mg}$ and $\mathrm{Ca}$ (Mengel and Kirby, 1978). 'Jade Scepter' leaves, however, had higher percentages of $\mathrm{Ca}$ and $\mathrm{Mg}$ than the other cultivars. There was no major differcnce between the micronutrient levels of Sierrablen-treated leaves and Osmocote-treated leaves (data not presented).

Survival for each of the cultivars for this experiment was calculated. 'Aphrodite' had 100\% survival rate except for treatments of 6 and $12 \mathrm{~g}$ using Sierrablen (Table 4). 'Hadspen Blue' had the smallest percent survival rate of all the cultivars in the experiment. 'Francec' had $100 \%$ survival rates using $6 \mathrm{~g} /$ pot Osmocote and 3 and 6 $\mathrm{g} /$ pot Sierrablen. 'Jade Scepter' had $100 \%$ survival in the control treatment. The best overall treatment for

Table 3. Nutrient analysis for Hosta plantaginea 'Aphrodite', Hosta 'Francee', and Hosta 'Jade Scepter' leaf tissue fertilized with Osmocote at four rates: 0 (control), 3,6 , and $12 \mathrm{~g} / 6$-inch pot.

\begin{tabular}{|c|c|c|c|c|c|c|c|c|c|c|c|c|c|}
\hline \multirow[b]{2}{*}{ Cultivar } & \multirow{2}{*}{$\begin{array}{c}\text { Treatment } \\
\text { (g/6-inch pot) }\end{array}$} & $\mathbf{N}$ & $\mathbf{P}$ & $\mathbf{K}$ & $\mathbf{C a}$ & Mg & Mn & $\mathbf{F e}$ & Cu & B & A1 & $\mathbf{Z n}_{\mathbf{n}}$ & $\mathbf{N a}$ \\
\hline & & \multicolumn{5}{|c|}{$(\%)$} & \multicolumn{7}{|c|}{$\left(\mu g \cdot g^{-1}\right)$} \\
\hline \multirow[t]{3}{*}{ Aphrodite } & 0 & 0.68 & 0.20 & 1.92 & 0.52 & 0.33 & 118 & 28 & 3 & 29 & 42 & 19 & 102 \\
\hline & 6 & 2.01 & 0.31 & 2.89 & 0.65 & 0.36 & 228 & 37 & 3 & 26 & 23 & 22 & 82 \\
\hline & 12 & 1.88 & 0.33 & 2.81 & 0.62 & 0.34 & 304 & 39 & 2 & 29 & 31 & 19 & 124 \\
\hline \multirow[t]{2}{*}{ Francee } & 0 & 0.68 & 0.18 & 1.49 & 0.49 & 0.23 & 68 & 22 & 3 & 15 & 21 & 23 & 133 \\
\hline & 12 & 2.46 & 0.36 & 2.79 & 0.75 & 0.31 & 155 & 51 & 3 & 23 & 17 & 26 & 300 \\
\hline \multirow[t]{4}{*}{ Jade Scepter } & 0 & 0.79 & 0.20 & 2.26 & 0.67 & 0.40 & 135 & 29 & 4 & 25 & 31 & 28 & 231 \\
\hline & 3 & 2.36 & 0.32 & 2.70 & 1.14 & 0.56 & 100 & 43 & 4 & 27 & 37 & 22 & 623 \\
\hline & 6 & 2.74 & 0.37 & 3.21 & 1.25 & 0.60 & 166 & 42 & 3 & 29 & 28 & 22 & 537 \\
\hline & 12 & 2.78 & 0.40 & 3.79 & 1.02 & 0.56 & 198 & 50 & 2 & 33 & 28 & 24 & 769 \\
\hline
\end{tabular}


Table 4. Percent survival for each of the five hosta cultivars grown at four rates of slow-release fertilizer: 0 (control), 3,6 , and $12 \mathrm{~g} / 6$-inch pot.

\begin{tabular}{|c|c|c|c|}
\hline Cultivar & Fertilizer & $\begin{array}{c}\text { Rate } \\
\text { (g/ pot) }\end{array}$ & $\begin{array}{c}\text { Survival } \\
(\%)\end{array}$ \\
\hline \multirow[t]{7}{*}{ Aphrodite } & Control & 0 & 100 \\
\hline & Osmocote & 3 & 100 \\
\hline & & 6 & 100 \\
\hline & & 12 & 100 \\
\hline & Sierra & 3 & 100 \\
\hline & & 6 & 83 \\
\hline & & 12 & 92 \\
\hline \multirow[t]{7}{*}{ Elegans } & Control & 0 & 92 \\
\hline & Osmocote & 3 & 92 \\
\hline & & 6 & 50 \\
\hline & & 12 & 67 \\
\hline & Sierra & 3 & 83 \\
\hline & & 6 & 50 \\
\hline & & 12 & 58 \\
\hline \multirow[t]{7}{*}{ Hadspen Blue } & Control & 0 & 67 \\
\hline & Osmocote & 3 & 25 \\
\hline & & 6 & 42 \\
\hline & & 12 & 17 \\
\hline & Sierra & 3 & 42 \\
\hline & & 6 & 17 \\
\hline & & 12 & 0 \\
\hline \multirow[t]{7}{*}{ Francee } & Control & 0 & 75 \\
\hline & Osmocote & 3 & 92 \\
\hline & & 6 & 100 \\
\hline & & 12 & 92 \\
\hline & Sierra & 3 & 100 \\
\hline & & 6 & 100 \\
\hline & & 12 & 75 \\
\hline \multirow[t]{7}{*}{ Jade Scepter } & Control & 0 & 100 \\
\hline & Osmocote & 3 & 92 \\
\hline & & 6 & 92 \\
\hline & & 12 & 42 \\
\hline & Sierra & 3 & 92 \\
\hline & & 6 & 25 \\
\hline & & 12 & 25 \\
\hline
\end{tabular}

hosta cultivar shoots is using Osmocote at a rate of $3 \mathrm{~g} / \mathrm{pot}$, or one-half the recommended rate for general nursery stock. These findings correspond Aden's recommendation for fertilization of hosta in the garden, which was one-half the recommended dos-

\section{Literature cited}

Adam, S. 1988. Nitrogen nutrition of container grown Hemerocallis. MS thesis, Univ. of Vermont, Burlington.

Aden, P. 1988. The hosta book. Timber Press, Portland, Ore.

Coleman, R.A., T. Mock, and T. Furuta. 1978. Effectiveness of Osmocote fertilizer influenced by placement and dosage. Calif. Agr. May:12-13.

Conover, C. A. and R.T. Poole. 1985. Influence of fertilizer source, rate, and application method on growth of Brassaia actinopbylla and Viburnum odoratissium. Proc. Fla. State Hort. Soc. 98:82-85.

Dahlquist, R.L. and J.W. Knoll. 1978. Inductively coupled plasma atomic emission spectrometer: Analysis of biological materials and major, trace, and ultra-trace elements. Applied Spectroscopy 32(2):129.

Isaac, R.A. and W.C. Johnson. 1976. Determination of total nitrogen in plant tissue, using a block digestor. J. Assn. Official Analytical Chemists 59:98-100.

Kovacic, M.T. and E.J. Holcomb. 1981. Effects of controlled-release fertilizers and application methods on growth and leaf elemental concentration of Kalanchoe blossfeldiana 'Pixie'. J. Amer. Soc. Hort. Sci. 106:549-552.

Lamont, G.P., G.C. Cresswell, and G.J. Griffith. 1992. Nutritional studies of Christmas bell. Austral. Plants 16:320-322.

Mengel, K, and E.A. Kirby. 1978. Principles of plant nutrition. Intl. Potash Inst., Bern, Switzerland.

Nau, J. 1996. Ball perenial manual: Propagation and production. Ball Publishing, Batavia, Ill

SAS Institute. 1989. SAS/STAT user's guide. version 6 . 4th ed. vols. 1-2. SAS Inst., Cary, N.C. 